\title{
Antibiotic production by intertidal sedimentary and porewater bacteria and the characterization of their prevalence in situ
}

\author{
Whitney Hook \& Craig Plante* \\ College of Charleston, Grice Marine Laboratory, Charleston, SC 29412, USA
}

Received 20 July 2017; Accepted 27 June 2019 Responsible Editor: Shigeaki Kojima

doi: $10.3800 /$ pbr.14.197

\begin{abstract}
In intertidal sediments, bacteria attach to sand grains in mixed-species biofilms and inhabit the surrounding porewater as free-living communities. The large densities, high species diversity, and complex spatial distribution of sediment-attached bacteria implicate inter-specific competition as a likely force in structuring sediment communities. Both sediment-attached and free-living bacteria secrete antibiotics as a common means of competition. To establish the frequency of antibiotic production, bacteria isolated from intertidal sediments and porewater were screened using a disc-diffusion assay. Among sediment-attached bacteria, 39\% displayed the ability to produce antibiotics, whereas significantly fewer of the porewater-associated bacteria $(23.5 \%)$ produced inhibitory compounds. Denaturing gradient gel electrophoresis (DGGE) was used to identify a selection of isolated antibiotic-producing bacteria within wholecommunity environmental samples. Through sequencing a region of the $16 \mathrm{~S}$ rRNA gene, the relative abundances of 4 antibiotic producers were established to be between $4.3-9.4 \%$ of the DGGE community profile. The high frequency of antibiotic-producing bacteria in sediments, and their significant quantitative contribution to the community composition, suggest that antibiosis likely plays a significant role in structuring benthic microbial communities.
\end{abstract}

Key words: antibiosis, inter-specific competition, intertidal, marine sediments

\section{Introduction}

The importance of bacteria as contributors to global biogeochemical cycling has been well established (Azam et al. 1994, Azam 1998, Simon et al. 2002). High numbers of bacteria associated with marine sediments hold the potential to significantly impact nutrient cycling in the world's oceans, via the transformation and remineralization of organic matter. Great functional diversity due to niche partitioning and high densities further contribute to the dominant impact marine sedimentary bacteria have on these processes (Torsvik \& Øvreås 2002).

Bacterial abundances in sediments remain remarkably consistent across broad geographic and environmental ranges. A density of $\sim 10^{9}$ bacterial cells $\mathrm{mL}^{-1}$ has been repeatedly observed in sediments despite differences in organic loads, substrate composition, porosity, and the composition of the bacterial assemblages (Schmidt et al. 1998,

*Corresponding author: Craig Plante; E-mail, plantec@cofc.edu
Musat et al. 2006, Rex et al. 2006). However, mechanisms that enforce this conformity of bacterial numbers are difficult to define given the complex spatial dynamics of sedimentary systems and variations in species richness and diversity that occur on a microscale (Torsvik et al. 1996, Stotzky 1997).

In intertidal sediments the majority of bacteria attach to sediment grains and form mixed-species biofilms (Decho 1990, Costerton et al. 1995). These biofilms form matrices that encase individual particles and protect microorganisms from environmental fluctuations in temperature, salinity, UV irradiation, desiccation, and sediment resuspension, all challenges associated with intertidal systems. The attached bacteria maintain a distinct spatial partitioning on the particle surface, where typically only $0.5-5 \%$ of particle surface area is inhabited (DeFlaun \& Mayer 1983). One mechanism that could maintain this spatial structuring and limit densities is intense competition. The "spheres of diffusional influence" around these small osmotrophs could dictate lower limits to nearest-neighbor distances, 
either via secretion of inhibitors (Schmidt et al. 1998) or by resource depletion (Vetter et al. 1998).

Competitive interactions are thought to be fundamental in shaping microbial communities and influencing diversity (Czárán et al. 2002, Long \& Azam 2001a). The secretion of antibiotic compounds, which inhibit or kill adjacent cells, is a characteristic form of antagonism that has been described in bacteria isolated from terrestrial soils, marine snow (Long \& Azam 2001a, Grossart et al. 2004), seaweeds (Lemos et al. 1986), and the surfaces of invertebrates (Gram et al. 2010). In theory, antibiotic-producing bacteria should be the dominant competitors in environments populated by bacterial species susceptible to the toxin (Adams et al. 1979, Chao \& Levin 1981). However, antibiotics are typically not effective against all other species and many competitors develop resistance through a variety of mechanisms, including genetic mutation and the acquisition of antibiotic-resistant genes via transformation or transduction (Hawkey 1998). The metabolic costs associated with antibiotic production or resistance creates tradeoffs between competitive ability and growth rate (Kang \& Park 2010). Inter-specific competition among antibioticproducing, susceptible, and resistant species can result in a type of tradeoff-mediated coexistence that is thought to maintain (Czárán et al. 2002) or even increase (Long \& Azam 2001b) species richness and diversity.

The prevalence of these competitive interactions is directly dependent on cell density, which influences how frequently a bacterium will encounter another cell (Simon et al. 2002). A higher frequency of antagonism among attached bacteria compared to free-living counterparts has been established in a few specific marine habitats, such as marine snow (Long \& Azam 2001a) and the surfaces of seaweeds and invertebrates (Burgess et al. 1999). The prevalence of antagonism has not been established for bacterial populations in marine sediments and the surrounding interstitial waters. Significant interspecific competition in sediments is likely, given the high densities at which they cohabitate (Schmidt et al. 1998, Torsvik et al. 1998, Musat et al. 2006).

As a transition between marine and terrestrial environments, the intertidal zone provides a unique opportunity to investigate the previously unexplored antagonisms among sedimentary and interstitial bacterial populations. The objectives of this study were to 1) establish the frequency of antibiotic production in intertidal sediment-attached bacteria and bacteria isolated from interstitial porewater, 2) quantify and compare the extent of antagonism, and 3) determine the relative in situ abundances of some of the selected isolates within the microbial community.

\section{Materials and Methods}

\section{Sediment sampling and preparation}

Intertidal sediment samples $(\mathrm{N}=8)$ were obtained dur- ing low tide from the semi-protected beach at Breach Inlet, South Carolina (32 $\left.46^{\prime} 36^{\prime \prime} \mathrm{N}, 79^{\circ} 48^{\prime} 42^{\prime \prime} \mathrm{W}\right)$ in November 2011. A sampling and extraction method adapted from Saager et al. (1990) was employed to collect and separate porewater from sediments. The uppermost $3 \mathrm{~mm}$ of sediment was aseptically collected to fill $10 \mathrm{~mL}$ of a $50 \mathrm{~mL}$ syringe containing a $0.7-\mu \mathrm{m}$ mesh glass-fiber filter (Whatman 8 GF-F). Samples were held on ice and processed immediately upon return to the laboratory. Syringes were centrifuged at $132 \times g$ for $15 \mathrm{~min}$ to allow porewater to filter through the GF-F into a collection tube. Remaining sediment samples $(\sim 1.5 \mathrm{~g})$ were diluted in $2 \mathrm{~mL}$ sterile natural seawater and sonicated (3-mm sonic probe) on ice at $40 \mathrm{~W}$ for two $30 \mathrm{~s}$ blasts, separated by $30 \mathrm{~s}$ on ice. After sediment particles settled, the supernatant extracts were collected. Serial dilutions $(1: 10,1: 100,1: 100)$ were prepared for both porewater and sediment fractions using sterile natural seawater. Marine Broth 2216 (Difco) medium at $50 \%$ concentration with $1.5 \%$ agar was used to spread plate each dilution. Plates were incubated at room temperature for $3 \mathrm{~d}$. The $1: 100$ dilution was used for colony selection based on density of colony forming units (between 30-300 CFUs).

All colonies on each $1: 100$ dilution plate were assigned a number. Twenty-five random numbers, within the bacterial count parameters for each of the 16 plates, were generated using R statistics software ( $\mathrm{R}$ Core Team 2010). The 400 colonies corresponding to the random numbers $(25 \times 8$ original samples) were picked and re-streaked on half-strength 2216 agar plates a minimum of three times to ensure culture purity, as determined by uniform morphology, color, and growth pattern.

\section{Antibiotic screening}

The Kirby-Bauer disc diffusion assay (Bauer et al. 1966) was used to identify antibiotic-producing bacteria. The 200 porewater and 200 sediment-derived isolates were grown in liquid (50\%) marine broth medium. Bacterial target lawns were prepared by inoculating molten marine broth agar with type strains of Bacillus subtilis (ATCC 19659), Escherichia coli (ATCC 25922), or Pseudomonas aeruginosa (ATCC 27853) before plating. These opportunistic pathogens are commonly employed in antibiotic screening, thus their use allows for direct comparison across studies. Sterile $6 \mathrm{~mm}$ paper discs were spaced around the plate, each inoculated with $10 \mu \mathrm{L}$ of a 24 -h isolate culture grown from a single plate-picked CFU. Each culture was tested in duplicate on plates that contained both a positive (50 $\mu \mathrm{g}$ $\mathrm{mL}^{-1}$ streptomycin) and negative (marine broth) control. Antibiotic production was indicated if the test strain maintained a clear zone of inhibition or reduced growth of the target strain. A clear zone also illustrated susceptibility of the target strain, indicating lack of resistance to the antibiotic(s). Inhibition was measured as total clearing zone diameter minus $6 \mathrm{~mm}$ (disc diameter) after 1, 5, and $10 \mathrm{~d}$ to quantify the strength of antagonism. Clearing 
zones measured on day 5 were used for subsequent analyses. Antagonistic interactions resulting in $\mathrm{a} \geq 1 \mathrm{~mm}$ diameter clear zone were considered positive, as this is a relevant scale for species interaction in marine communities (Long \& Azam 2001b, Rypien et al. 2010). The proportions of inhibitory bacteria from porewater samples and sediment surfaces were compared using a Fisher exact test (Fisher 1958). Inhibition zone diameters produced by porewater and sediment isolates were compared using the nonparametric Mann-Whitney rank sum test because data were not normally distributed. Clearing zone diameters were compared among target strains (P. aeruginosa, E. coli, and $B$. subtilis) using a Kruskal-Wallis one-way analysis. All statistical tests were performed using $\mathrm{R}$ statistics software (R Core Team 2010).

\section{Environmental screening}

To confirm that these anti-bacterial compounds were also effective against indigenous bacteria, six isolates (3 sediment-attached and 3 from porewaters) displaying strong antibiotic-production capabilities, determined by clearing zone size and breadth of activity against type strains, were selected and assayed against 36 environmental targets isolated in this study. All 36 selected targets were among the many environmental strains that tested negative for production of antibiotic compounds in disc diffusion assays against the type strains. In addition, these strains were among those tested against each other and showed no inhibitory capabilities against other environmental isolates. A secondary goal was to ensure diversity of target strains based on morphology, pigmentation, and growth characteristics. Fisher's exact test was employed to ascertain whether porewater- or sediment-isolated antibiotic producers inhibited a greater proportion of the 36 target strains. We tested whether antibiotic producers isolated from porewater or sediment grains were more (or less) likely to inhibit target bacteria from the same habitat using the Mantel-Haenszel procedure to test odds ratios for homogeneity (Sokal \& Rohlf 1995). We also compared strength of inhibition (clear zone size) by origin (porewater or particle-attached) of producers and targets using Kruskal-Wallis tests.

A set of three target strains was then selected based on mixed patterns of resistance and susceptibility to compound(s) produced by the chosen producers. This subset of six antibiotic producing and three non-producing bacteria was used for further community-level analysis, described below.

\section{Denaturing gradient gel electrophoresis (DGGE)}

Denaturing gradient gel electrophoresis (DGGE) (Muyzer et al. 1993) was utilized to establish in situ presence and relative abundances of the 9 selected antibiotic-producing (6) and target bacteria (3). Intertidal sediment and porewater samples $(\mathrm{N}=8$ each) from Breach Inlet, SC were processed as previ- ously described. DNA was extracted from the sediment and porewater fractions, or directly from bacterial monocultures, by phenol:chloroform:isoamyl and ethanol precipitation (Miller et al. 1999). Primer 341F(5'-CCT ACG GGA GGC AGC AG-3'; positions 341-357 of $E$. coli $16 \mathrm{~S}$ rRNA) and primer 786R(5'-GAC TAC CAG GGT ATC TAA TC-3'; positions 805 to 786 of E. coli $16 \mathrm{~S}$ rRNA) were used for amplification. PCR was performed using a Bio-Rad iCycler (Bio-Rad Laboratories, Hercules, $\mathrm{CA})$ using the following program: $1 \mathrm{~min}$ of initial denaturation at $95^{\circ} \mathrm{C}$ followed by 26 cycles of denaturation $(30 \mathrm{~s}$ at $\left.95^{\circ} \mathrm{C}\right)$, annealing $\left(30 \mathrm{~s}\right.$ at $\left.50^{\circ} \mathrm{C}\right)$, and extension $(30 \mathrm{~s}$ at $72^{\circ} \mathrm{C}$ ), with a final extension at $72^{\circ} \mathrm{C}$ for $4 \mathrm{~min}$. PCR products were run on a $6 \%$ polyacrylamide gel with a $35-55 \%$ denaturing gradient at $70 \mathrm{~V}$ for $16 \mathrm{~h}$ on the $\mathrm{D}$-Code $\mathrm{Mu}$ tation Detection System (Bio-Rad Laboratories, Hercules, CA, USA). Gels were stained with SYBR Gold for visualization under UV light. Relative abundances of bacterial operational taxonomic units (OTUs) within community samples were determined using band intensity as quantified with Quantity One ${ }^{\mathrm{TM}}$ (Bio-Rad Laboratories) image analysis software relative to the total intensity of all bands in a given lane.

\section{S rRNA gene sequencing}

Gel lanes were alternated between isolate monocultures and community samples so that isolate DNA bands were directly adjacent to community profiles. DNA bands within environmental samples corresponding to individual isolate bands were picked directly from the gel, along with each of the pure-culture isolate bands. Band DNA was eluted in water overnight at $4^{\circ} \mathrm{C}$ before being PCR-amplified with the same 341F-786R primer set, minus the $3^{\prime}-\mathrm{GC}$ clamp on the forward primer. Presence of the bacterial isolate within the sediment or porewater community was confirmed by $16 \mathrm{~S}$ rRNA gene sequencing for positive identification. The entire 16S rRNA gene of the 9 selected environmental isolates was sequenced with primers $8 \mathrm{~F}, 341 \mathrm{~F}$, 1070F, 530R, 786R, and 1492R for complete coverage (Macrogen USA Inc., Rockville, MD). These samples and DGGE-picked bands were purified post-PCR using a Stop Solution/Glycogen mixture (3 M sodium acetate, $100 \mathrm{mM}$ $\mathrm{Na}_{2}$-EDTA and $20 \mathrm{mg} \mathrm{mL}^{-1}$ glycogen) with ethanol precipitation series prior to sequencing. Consensus sequences were generated using BioEdit software. Band-picked DNA sequences were aligned with potential isolate matches using NCBI basic local alignment search tool (BLAST). The sequences were submitted to the National Center for Biotechnology Information Genbank database under the accession numbers MN066570-MN066577.

\section{Results}

\section{Antibiotic Screening}

Mean CFU densities for porewater and particle-attached 
Table 1. Number of sediment- and porewater-associated bacterial isolates (of 200) that inhibited each type-strain target

\begin{tabular}{cccc}
\hline Origin of & \multicolumn{3}{c}{ Target Species } \\
\cline { 2 - 4 } Antibiotic & Pacillus subtilis & $\begin{array}{c}\text { Pseudomonas } \\
\text { aeruginosa }\end{array}$ & Escherichia coli \\
Producers & Bar & 9 & 11 \\
Sediment & 72 & 4 & 21 \\
Porewater & 45 & & \\
\hline
\end{tabular}

samples were $7.5 \times 10^{4}$ cells $\mathrm{mL}^{-1}$ and $1.81 \times 10^{5}$ cells $\mathrm{g}^{-1}$, respectively. Of the 400 colony isolates screened for antibiotic production, $125(31.3 \%)$ were found to inhibit at least one of the bacterial type-strain targets, B. subtilis, $E$. coli, or $P$. aeruginosa. Sediment-attached bacteria accounted for the majority of antibiotic-producers with 78 of $200(39 \%)$ of isolates demonstrating antibiosis. This was significantly higher than the $47(23.5 \%)$ of free-living porewater isolates that displayed antibiotic-production capabilities $(p<0.010$; Fisher exact test). A large majority of antibiotic producers, 117 out of 125 total strains, inhibited the growth of $B$. subtilis (Table 1). In contrast, $P$. aeruginosa proved the most resistant, with susceptibility to just 13 of the tested strains, whereas E. coli was inhibited by 32 strains. In total, only 4 of the tested isolates inhibited all three target type-strains.

\section{Strength of Antagonism}

Inhibition zone diameter was used to quantify the intensity of antibiosis against bacterial targets. Sediment and porewater-derived isolates displayed no difference in average clearing zone diameter across all type-strain bacterial targets, with 4.82 and $4.53 \mathrm{~mm}$ averages, respectively (Mann-Whitney rank sum test: $p=0.147$ ). A larger proportion of the sediment-attached producers displayed only mild inhibitory capabilities, i.e., the zone of target growth clearing was $\leq 2 \mathrm{~mm}$ ( $25 \%$ vs. $7.1 \%$ for porewater isolates; Fig. 1). The most common pattern of antagonism resulted in target inhibition of $\sim 4 \mathrm{~mm}$. When broken down by target type strain, the same inhibition pattern emerged for both sediment- and porewater-derived antibiotic producers, with the exception that more sediment isolates tested against $B$. subtilis exhibited weak $(<2 \mathrm{~mm})$ inhibition. There was an inverse relationship between the number of producers that inhibited a target and the size of the clearing zone. While the largest number of producers affected the growth of $B$. subtilis, the antagonistic relationships resulted in the lowest average strength of inhibition (porewater isolate mean $=4.2 \mathrm{~mm}$; sediment isolate mean $=4.3 \mathrm{~mm}$ ). On the other hand, $P$. aeruginosa was susceptible to the least number of compoundproducing isolates, but when inhibited, it was to a larger degree (porewater isolate mean $=6.5 \mathrm{~mm}$; sediment isolate mean $=5.8 \mathrm{~mm}$; Fig. 1). Mean clear zone diameters for porewater and sediment isolates against E. coli were 4.9 and $5.2 \mathrm{~mm}$, respectively. There was no significant dif-
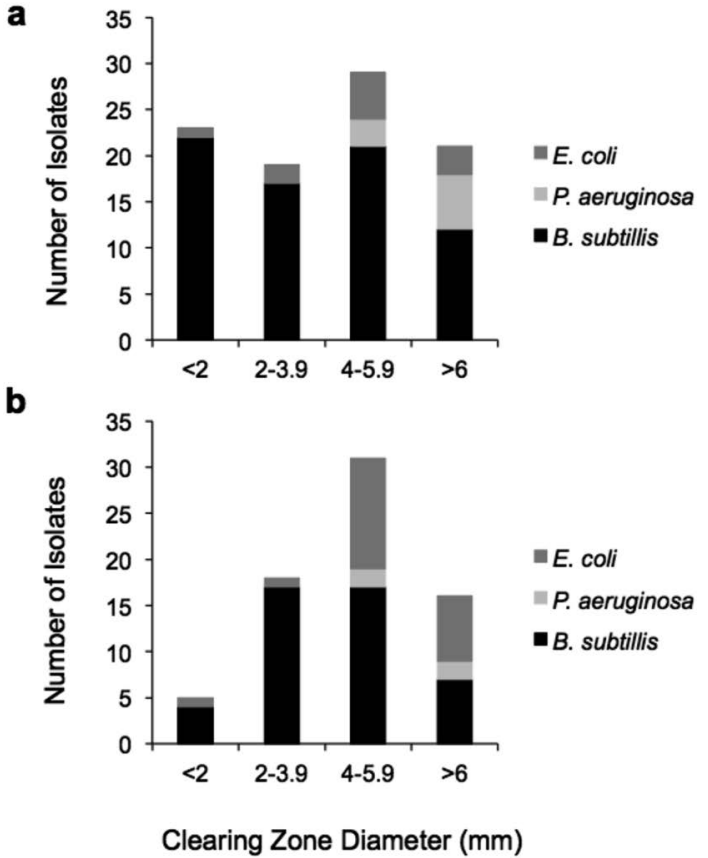

Fig. 1. Frequency distribution of inhibition strength against type strains for antibiotic-producing bacteria isolated from a) sediment, and b) porewater.

ference in the clearing zone diameter of porewater and sediment producers against any of the type-strain targets ( $P$. aeruginosa, $p=0.743 ; B$. subtilis, $p=0.239 ; E$. coli, $p=0.448$; Mann-Whitney rank sum tests). The average clearing zone diameter of each target strain was not different among porewater antibiotic producers $(p=0.153$; Kruskal-Wallis), but a significantly different inhibition pattern was seen among sediment-associated bacteria ( $p=0.004$; Kruskal-Wallis) with greater average clearing zone diameters against $P$. aeruginosa compared to $B$. subtilis $(p<0.05$; Dunn's method). No significant differences existed when taking other pairwise comparisons into account: P. aeruginosa vs. E. coli and E. coli vs. B. subtilis ( $p>0.05$; Dunn's method).

\section{Environmental Screening and Antagonism}

The 6 selected porewater- and sediment-associated antibiotic producers were identified through 16S rRNA gene sequencing (described below) and screened against a set of 25 sediment- and 11 porewater-derived environmental target strains (Fig. 2). Porewater-associated antibiotic producers inhibited a higher total $\%$ of the target strains than the sediment-associated antibiotic producers did $(p<0.001$, Fisher's exact test; Fig. 2). However, there was no correspondence between environmental origin of producers and targets, i.e., porewater-isolated antibiotic producers inhibited a comparable proportion of targets isolated from porewater or sediment grains $(0.1<p<0.5$; Mantel-Haenszel test), as did sediment-associated producers $(p>0.9)$. Clearing zone diameter did not differ between porewater $($ mean $=5.9 \mathrm{~mm}$ ) and sediment-associated tar- 
gets $($ mean $=7.5 \mathrm{~mm})(p=0.807$, Kruskal-Wallis) but clear zones were significantly larger for porewater antiobiotic producers (mean $=12.5 \mathrm{~mm}$ ) as compared to those isolated from sediments (mean $=1.5 \mathrm{~mm} ; \mathrm{p}<0.001$ ).

\section{DGGE and DNA Sequencing}

Prevalence of antibiotic producers within intertidal bacterial communities was verified using DGGE band alignment with isolates, followed by $16 \mathrm{~S}$ rRNA gene sequencing. Four producers of antibacterial compounds and one non-producing target strain were positively identified within whole community DNA profiles by alignment of gene sequences (Table 2). Relative abundances of these isolates ranged from $4.3-11.3 \%$ of the DGGE community profile as determined by DNA band intensities (Table 2 and Fig. 3). Complete 16S rRNA gene sequencing of the 6 selected antibacterial compound producing and 3 target bacteria revealed species belonging to Proteobacteria, Firmicutes, and Actinobacteria phyla. Within the Gramnegative Proteobacteria, four genera were represented:

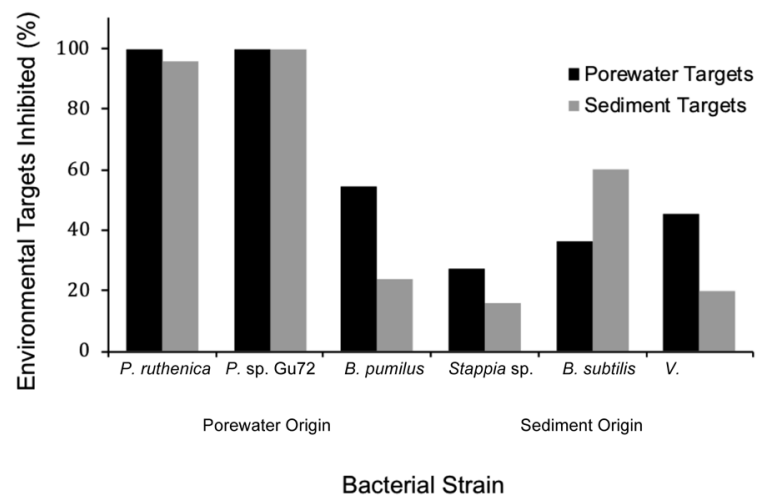

Fig. 2 Percentage of porewater $(\mathrm{N}=11)$ and sediment $(\mathrm{N}=25)$ environmental bacterial targets inhibited by select antibioticproducing strains of porewater or sediment origin.
Pseudoalteromonas, Roseivivax, Stappia, and Vibrio. Two Gram-positive genera, Bacillus and Agrococcus, were also detected (Table 2). Of the isolates that were not detected within environmental samples, three were Bacillus spp. and one was a species of Actinobacteria.

\section{Discussion}

Nearly $40 \%$ of sediment-attached bacteria inhibited target strains, suggesting that production of antibacterial compounds is not rare among intertidal bacteria. Although
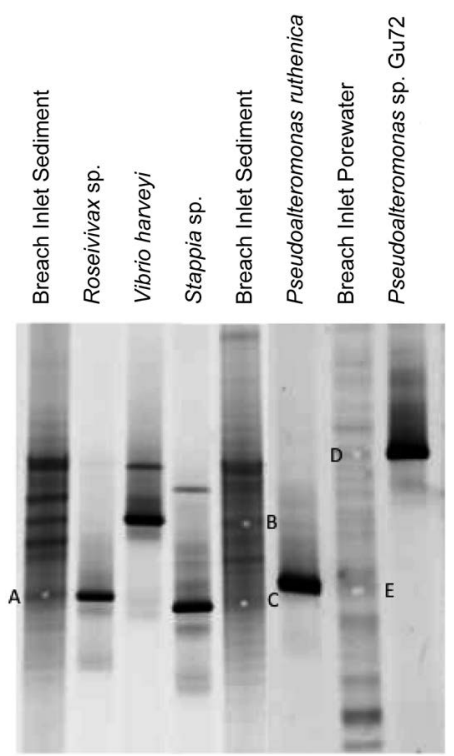

Fig. 3 DGGE gel image depicting banding patterns from environmental sediment and porewater samples in comparison to bacterial isolates. Holes in gel (and letters A-E) indicate those matching bands that were DNA sequenced (16S rRNA genes) to confirm matches and identity.

Table 2. 16S rRNA gene sequence identification of selected antibiotic-producing and target strains with DGGE \% band match (and base pair ratio) comparisons. Letters A-E correspond to letters on Fig. 3. Community profile percentages were determined from relative band intensities in representative sediment and porewater samples (see Fig. 3)

\begin{tabular}{|c|c|c|c|c|c|c|c|}
\hline $\begin{array}{l}\text { Isolate Origin } \\
\text { and Type }\end{array}$ & Phylum & $\begin{array}{l}\text { Closest Relative } \\
\text { (GenBank) }\end{array}$ & $\begin{array}{c}\text { GenBank } \\
\text { Accession } \\
\text { Number }\end{array}$ & $\begin{array}{l}\text { 16S rRNA Gene } \\
\text { Similarity \% } \\
\text { (bp/bp) }\end{array}$ & $\begin{array}{l}\text { DGGE } \\
\text { Band Match } \\
\text { Identifier }\end{array}$ & $\begin{array}{l}\text { \% Identity } \\
\text { Match } \\
\text { (bp/bp) }\end{array}$ & $\begin{array}{c}\% \text { of } \\
\text { Community } \\
\text { Profile }\end{array}$ \\
\hline \multirow{3}{*}{$\begin{array}{l}\text { Porewater } \\
\text { Antibiotic- } \\
\text { Producers }\end{array}$} & Proteobacteria & $\begin{array}{l}\text { Pseudoalteromonas ruthenica } \\
\text { strain S3258 }\end{array}$ & FJ457211.1 & $100(1361 / 1361)$ & $\mathrm{E}$ & $98(311 / 317)$ & 9.4 \\
\hline & Proteobacteria & Pseudoalteromonas sp. Gu72 & GU361127.1 & $99(1453 / 1455)$ & $\mathrm{D}$ & $98(375 / 382)$ & 4.3 \\
\hline & Firmicutes & Bacillus pumilus strain SB 3002 & GU191914.1 & $100(1463 / 1463)$ & - & - & - \\
\hline \multirow{3}{*}{$\begin{array}{l}\text { Sediment } \\
\text { Antibiotic- } \\
\text { Producers }\end{array}$} & Proteobacteria & Stappia sp. M8 & AY307927.1 & $100(1415 / 1415)$ & $\mathrm{C}$ & $99(361 / 364)$ & 8.1 \\
\hline & Firmicutes & $\begin{array}{l}\text { Bacillus subtilis strain NBRC } \\
\quad 13722\end{array}$ & AB680489.1 & $99(1440 / 1441)$ & - & - & - \\
\hline & Proteobacteria & Vibrio harveyi strain XC08001 & FJ605242.1 & $99(1509 / 1524)$ & B & $99(311 / 314)$ & 8.5 \\
\hline \multirow{3}{*}{$\begin{array}{l}\text { Sediment } \\
\text { Targets }\end{array}$} & Firmicutes & Bacillus pumilus strain SB 3002 & GU191914.1 & $99(1492 / 1501)$ & - & - & - \\
\hline & Actinobacteria & Agrococcus jejuensis $\mathrm{Pp} 5$ & JQ861540.1 & $96(1280 / 1333)$ & - & - & - \\
\hline & Proteobacteria & Roseivivax sp. NT N52 & AB166990.1 & $99(1357 / 1361)$ & A & $99(360 / 364)$ & 11.3 \\
\hline
\end{tabular}


not previously observed in sediments (Nair \& Simidu 1987, Kummerer 2009), comparable proportions of producers have been noted in bacteria attached to particles in the water column (53.5\%, Long \& Azam 2001a). In our study, this proved to be a significantly higher frequency than observed among free-living (porewater) bacteria, of which $23.5 \%$ produced inhibitory compounds. This last finding is consistent with previous studies that have compared surface-attached and proximate free-living bacteria in coastal waters (Nair \& Simidu 1987, Long \& Azam 2001a).

The higher frequency of antagonism associated with sedimentary bacteria corresponds to bacterial densities that are 1,000-10,000-fold higher than in seawater (Schmidt et al. 1998, Tholosan \& Bianchi 1998). Nutrient uptake by microbial osmotrophs causes limited zones of depletion, typically taken to be $<10 \mu \mathrm{m}$ from the cell surface (Jumars 1993, Jumars et al. 1993). Substrate competition results when these zones of depletion overlap. At seawater densities $\left(\sim 10^{6}\right.$ cells $\left.\mathrm{cm}^{-3}\right)$, foraging zones would rarely intersect, whereas typical abundances in sediments $\left(\sim 10^{9}\right.$ cells $\left.\mathrm{cm}^{-3}\right)$ correspond to mean nearest-neighbor distance of $10 \mu \mathrm{m}$ (Vetter et al. 1998). More dense bacterial populations may also allow for the utilization of cell-cell communication, or quorum sensing, to trigger or signal production (Gram et al. 2002). Furthermore, free-living bacteria don't benefit from surface adsorption and would be subject to rapid diffusional loss of secretions in the water column (Simon et al. 2002). Spatial stability, diffusional constraints, and high cell densities and activities associated with particle habitation may combine to favor the energetic investment in antibiotics to defend against competitors.

In our study, most porewater isolates producing antibiotics did so at intermediate strength $(2-6 \mathrm{~mm}$ zones in Kirby-Bauer diffusion assays) while sediment-associated bacteria produced larger proportions of weak or strong inhibitors $(\leq 2 \mathrm{~mm}$ and $>6 \mathrm{~mm}$ ). Weak antibiotic production among porewater isolates, i.e., $\leq 2 \mathrm{~mm}$, was uncommon. This may reflect the inefficiency of antibiotic use in the water column, where competitors would frequently be too distant to encounter inhibitors secreted in low concentrations. Free-living species of bacteria typically display higher motility and the capacity to move away from unfavorable conditions (Grossart et al. 2001), therefore production of relatively high concentrations or more potent antibiotics could be required to inhibit competitors. Producing relatively small amounts of antibiotic is perhaps a better competitive strategy for surface-associated bacteria that benefit from diffusional constraints and immobilization of secretions within the EPS matrix (Plante et al. 1990, Grossart et al. 2004). Use of even stronger antibiotics by sediment-attached bacteria could represent an offensive tactic (e.g., displacement of a prior colonizer) rather than a defensive response to invaders.

However, antibiotics must be produced in sufficient quantity to be effective. It is possible that the weak pro- duction observed by many sediment-attached isolates would indeed be produced in situ at sub-inhibitory concentrations, possibly with an altogether alternative function. Recent studies have demonstrated that compounds thought to be antibiotics instead acted as intra- or interspecific signaling molecules at low concentrations (Goh et al. 2002, Yim et al. 2007) or altered gene expression, e.g., stimulated biofilm formation, rather than inhibited neighbors (Dietrich et al. 2008). As previously argued, existence in biofilms and communal living is much more prevalent among bacteria associated with sediment grains than in free-living forms.

It should also be noted that drawing ecological conclusions from lab culture results can be tenuous, especially inferences about quantitative effects (inhibition strength) versus simple presence/absence of potential inhibitors. Cell density, habitat, and lifestyle, all of which will vary markedly when grown on 2216 agar as compared to life in situ, each influence antibiotic production (Drenkard 2003, Hibbing et al. 2010). Even within the laboratory, production of antibiotics can vary based on culture conditions, e.g., bromide concentration, surface hydrophobicity (Ivanova et al. 1998). Perhaps the best that can be concluded from measures of in vitro inhibition strength is that species producing the largest zones of clearing are best targets for study of competitive interactions in natural habitats.

We found that both attached and porewater marine bacteria that inhibited type cultures also were antagonistic against a variety of native bacterial isolates. These findings corroborate prior studies that likewise demonstrated inhibition of bacterial targets isolated from the habitat of producers (Nair \& Simidu 1987, Long \& Azam 2001a, Rao et al. 2005). In our study, the two representatives of the Pseudoalteromonas genus exhibited the broadest range of inhibition, both inhibiting close to $100 \%$ of environmental targets. Members of this genus are well known to produce a diverse range of antibiotics (Bowman et al. 2007) and have been used commonly in studies on interference competition (Rao et al. 2005, Franks et al. 2006, Rao et al. 2006). Among the other genera tested in the current study (Bacillus, Stappia, Vibrio), representative species have also been previously shown to secrete antibiotics (e.g., Das et al. 2008, Ali et al. 2011, Long \& Azam 2001a, resp.). Our selected porewater isolates inhibited more environmental targets than did our sediment-attached isolates (Fig. 2). Although this result runs counter to prior studies (Nair \& Simidu 1987, Long \& Azam 2001a), our sample size was so small (only 3 antibiotic producers from each habitat type) that this comparison has little meaning. Long and Azam (2001a) also found that the capacity of particle-attached bacteria to chemically inhibit free-living bacteria was greater than the ability of free-living bacteria to inhibit attached bacteria. In contrast, producers in our study showed no bias with respect to whether targets originated from porewater or sediment grains. Because sediment-attached and free-living bacteria likely encounter one another fre- 
quently in this turbulent habitat, patterns of resistance may already exist due to exposure to secreted compounds in nature. In addition, significant overlap in OTUs has been found to exist in attached and free-living fractions (Mallet et al. 2014).

The abundance of antibiotic-producing bacteria within intertidal sediment and associated porewater communities in situ has not been previously established. Direct methods of quantification are limited by the low percentages of culturable bacteria from the environment, whereas metagenomic analyses are restricted by a lack of knowledge regarding genes that regulate and would indicate antibacterial production. Even with our limited sequencing effort, it was possible to identify several producers as relevant members of microbial porewater and sediment-based communities utilizing DGGE analysis. Individual species of antibiotic producers comprised large fractions (up to 9.4\%) of the relative lane band intensity, suggesting a significant quantitative contribution to the sedimentary bacterial assemblage. However, due to preferential PCR amplification and heteroduplex formation (multiple bands from a single OTU), DGGE band intensity is not a quantitative indicator of community OTU abundance (Neilson et al. 2013). Nonetheless, Murray et al. (1996) showed a correspondence between band intensity and relative abundance of template DNA in constructed communities and that heteroduplex formation does not significantly interfere with DGGE analysis of complex natural communities. Thus, the strong representation of producers in the DGGE gels of our beach samples hints at the ecological importance of these antagonistic bacteria-bacteria interactions.

Of the six antibiotic-producing isolates identified through 16S rRNA gene sequencing, three were $\gamma$ Proteobacteria, including two species of Pseudoalteromonas. Gram-negative bacteria in general dominate marine sediments (Buck 1982, Moriarty \& Hayward 1982) and these particular groups have been identified as dominant antibiotic producers in various marine systems (Long \& Azam 2001a, Grossart et al. 2004, Musat et al. 2006). In contrast, two of the antibiotic producers and one target strain were Gram-positive Bacillus spp., which are not typically major contributors to bacterial communities in marine sediments (Moriarty \& Hayward 1982). However, Gram-positive bacteria are relatively more common in nearshore sediments, which could reflect a greater degree of terrigenous input. In addition, Gram-positive bacteria generally exhibit broad salinity tolerance (Holt et al. 1994), which could further explain their relatively high representation in estuarine habitats (Stevens et al. 2007), including in the present study.

In conclusion, several bacterial species in marine sediments and porewaters produced antibiotics that inhibited both type strains and environmental bacteria in the laboratory. Producers were relatively more common among sediment-attached bacteria than their free-living counterparts in porewaters, likely due to the higher abundances and dif- fusional limitations in biofilms. Marine sediments appear to be potential sources of novel antibiotics as well as ideal locales to study interference competition among bacteria.

\section{Acknowledgements}

This work was supported by funding provided by the Biology Department and the Graduate School of the College of Charleston. Grice Marine Laboratory contribution \#527.

\section{References}

Adams J, Kinney T, Thompson S, Rubin L, Helling RB (1979) Frequency-dependent selection for plasmid-containing cells of Escherichia coli. Genetics 91: 627-637.

Ali AI-B, El Bour M, Ktari L, Bolhuis H, Ahmed M, Boudabbous A, Stal LJ (2011) Antimicrobial potentialities of Ulva rigida epiphytic bacteria. Planta Med 77:PH8.

Azam F (1998) Microbial control of oceanic carbon flux: the plot thickens. Science 280: 694-696.

Azam F, Smith DC, Steward GF, Hagström ^ (1994) Bacteriaorganic matter coupling and its significance for oceanic carbon cycling. Microb Ecol 28: 167-179.

Bauer AW, Kirby WMM, Sherris JC, Turk M (1966) Antibiotic susceptibility testing by a standardized single disk method. Am J Clin Pathol 45: 493-496.

Bowman JP (2007) Bioactive compound synthetic capacity and ecological significance of marine bacterial genus Pseudoalteromonas. Mar Drugs 5: 220-241.

Buck JD (1982) Nonstaining ( $\mathrm{KOH})$ method for determination of Gram reactions of marine bacteria Appl Environ Microbiol 44: 992-993.

Burgess JG, Jordan EM, Bregu M, Mearns-Spragg A, Boyd KG (1999) Microbial antagonism: a neglected avenue of natural products research. Prog Ind Microbiol 35: 27-32.

Chao L, Levin BR (1981) Structured habitats and the evolution of anticompetitor toxins in bacteria. Proc Natl Acad Sci USA 78: 6324-6328.

Costerton JW, Lewandowski Z, Caldwell DE, Korber DR, Lappin-Scott HM (1995) Microbial biofilms. Annu Rev Microbiol 49: 711-745.

Czárán TL, Hoekstra RF, Paige L (2002) Chemical warfare between microbes promotes biodiversity. Proc Natl Acad Sc USA 99: 786-790.

Das P, Mukherjee S, Sen R (2008) Antimicrobial potential of a lipopeptide biosurfactant derived from a marine Bacillus circulans. J Appl Microbiol 104: 1675-1684.

Decho AW, (1990) Microbial exopolymer secretions in ocean environments: their role(s) in food webs and marine processes. Oceanogr Mar Biol Annu Rev 28: 73-153.

DeFlaun MF, Mayer LM (1983) Relationships between bacteria and grain surfaces in intertidal sediments. Limnol Oceanogr 28: 873-881.

DeLong EF, Franks DG, Alldredge AL (1993) Phylogenetic diversity of aggregate-attached vs. free-living marine bacterial assemblages. Limnol Oceanogr 38: 924-934.

Dietrich LEP, Teal TK, Price-Whelan A, Newman DK (2008) 
Redox-active antibiotics control gene expression and community behavior in divergent bacteria. Science 321: 1203-1206.

Drenkard E (2003) Antimicrobial resistance of Pseudomonas aeruginosa biofilms. Microb Infect 5: 1213-1219.

Fisher RA (1958) Statistical Methods for Research Workers, 13th edition. Hafner, New York, 372 pp.

Franks A, Egan S, Holmstrom C et al. (2006) Inhibition of fungal colonization by Pseudoalteromonas tunicata provides a competitive advantage during surface colonization. Appl Environ Microbiol 72: 6079-6087.

Goh EB, Yim G, Tsui W et al. (2002) Transcriptional modulation of bacterial gene expression by subinhibitory concentrations of antibiotics. Proc Natl Acad Sci USA 99: 17025-17030.

Gram L, Grossart H-P, Schlingloff A, Kiørboe T (2002) Possible quorum sensing in marine snow bacteria: production of acylated homoserine lactones by Roseobacter strains isolated from marine snow. Appl Environ Microbiol 68: 4111-4115.

Gram L, Melchiorsen J, Bruhn JB (2010) Antibacterial activity of marine culturable bacteria collected from a global sampling of ocean surface waters and surface swabs of marine organisms. Mar Biotechnol 12: 439-451.

Grossart H-P, Riemann L, Azam F (2001) Bacterial motility in the sea and its ecological implications. Aquat Microb Ecol 25: 247-258.

Grossart H-P, Schlingloff A, Bernhard M, Simon M, Brinkhoff T (2004) Antagonistic activity of bacteria isolated from organic aggregates of the German Wadden Sea. FEMS Microbiol Ecol 47: 387-396.

Hawkey PM (1998) The origins and molecular basis of antibiotic resistance. Brit Med J 317: 657-660.

Hibbing ME, Fuqua C, Parsek MR, Peterson SB (2010) Bacterial competition: surviving and thriving in the microbial jungle. Nat Rev Microbiol 8: 15-25.

Holt JG, Krieg NR, Sneath PHA, Staley JT, Williams, ST (1994) Bergey's Manual of Determinative Bacteriology, 9th edition. Williams \& Wilkins, Baltimore, 787 pp.

Ivanova EP, Nicolau DV, Yumoto N, Taguchi T, Okamoto K, Tatsu Y, Yoshikawa S (1998) Impact of conditions of cultivation and adsorption on antimicrobial activity of marine bacteria. Mar Biol 130: 545-551.

Jumars PA (1993) Concepts in Biological Oceanography. Oxford University Press, New York, 347 pp.

Jumars PA, Deming JW, Hill PS, Karp-Boss L, Yager PL, Dade, WB (1993) Physical constraints on marine osmotrophy in an optimal foraging context. Aquat Microb Ecol 7: 121-159.

Kang Y-S, Park W (2010) Trade-off between antibiotic resistance and biological fitness in Acinetobacter sp. strain DR1. Environ Microbiol 12: 1304-1318.

Kümmerer K (2009) Antibiotics in the aquatic environment-a review-part I. Chemosphere 75: 417-434.

Lemos ML, Toranzo AE, Barja LJ (1986) Antibiotic activity of epiphytic bacteria isolated from intertidal seaweeds. Microb Ecol 11: 149-163.

Long RA, Azam F (2001a) Antagonistic interactions among marine pelagic bacteria. Appl Environ Microbiol 67: 4975-4983.

Long RA, F. Azam F (2001b) Microscale patchiness of bacterioplankton assemblage richness in seawater. Aquat Microb Ecol 26: $103-113$.
Mallet C, Agogue H, Bonnemoy F, Guizien K, Orvain F, Dupuy C (2014) Structures of benthic prokaryotic communities and their hydrolytic enzyme activities resuspended from samples of intertidal mudflats: An experimental approach. J Sea Res 92: $158-169$.

Miller DN, Bryant JE, Madsen EL, Ghiorse WC (1999) Evaluation and optimization of DNA extraction and purification procedures for soil and sediment samples. Appl Environ Microbiol 65: 4715-4724.

Moriarty DJW, Hayward AC (1982) Ultrastructure of bacteria and the proportion of Gram-negative bacteria in marine sediments. Microb Ecol 8: 1-14.

Murray, AE, Hollibaugh, JT, Orrego C (1996) Phylogenetic compositions of bacterioplankton from two California estuaries compared by denaturing gradient gel electrophoresis of $16 \mathrm{~S}$ rDNA fragments. Appl. Environ. Microbiol. 62: 2676-2680.

Musat N, Werner U, Knittel K, Kolb S, Dodenhof $\mathrm{T}$, van Beusekom JEE, de Beer D, Dubilier N, Amann R (2006) Microbial community structure of sandy intertidal sediments in the North Sea, Sylt-Rømø Basin, Wadden Sea. Syst Appl Microbiol 29: 333-348.

Muyzer G, De Waal EC, Uitierlinden AG (1993) Profiling of complex microbial populations by denaturing gradient gel electrophoresis analysis of polymerase chain reaction-amplified genes coding for 16S rRNA. Appl Environ Microbiol 59: 695-700.

Nair S, Simidu U (1987) Distribution and significance of heterotrophic marine bacteria with antibacterial activity. Appl Environ Microbiol 53: 2957-2962.

Neilson JW, Jordan FL, Maier RM (2013) Analysis of artifacts suggests DGGE should not be used for quantitative diversity analysis. J Microbiol Meth 92: 256-263.

Plante CJ, Jumars PA, Baross JA (1990) Digestive associations between marine detritivores and bacteria. Annu Rev Ecol Syst 21: 93-127.

Rao D, Webb JS, Kjelleberg S (2005) Competitive interactions in mixed-species biofilms containing the marine bacterium Pseudoalteromonas tunicata. Appl Environ Microbiol 71: 1729-1736.

Rao D, Webb JS, Kjelleberg S (2006) Microbial colonization and competition on the marine alga Ulva australis. Appl Environ Microbiol 72: 5547-5555.

R Development Core Team (2010) R: a Language and Environment for Statistical Computing. R Foundation for Statistical Computing, Vienna. Available at: http://www.R-project.org (accessed on November 12, 2010).

Rex MA, Etter RJ, Morris JS, Crouse J, McClain CR, Johnson NA, Stuart CT, Deming JW, Thies R, Avery R (2006) Global bathymetric patterns of standing stock and body size in the deep-sea benthos. Mar Ecol Prog Ser 317: 1-8.

Rypien KL, Ward JR, Azam F (2010) Antagonistic interactions among coral-associated bacteria. Environ Microbiol 12: 28-39.

Saager PM, Sweerts J-P, Ellermeijer HT (1990) A simple porewater sampler for coarse, sandy sediments of low porosity. Limnol Oceanogr 35: 747-751.

Schmidt JL, Deming JW, Jumars PA, Keil RG (1998) Constancy of bacterial abundance in surficial marine sediments. Limnol Oceanogr 43: 976-982. 
Simon M, Grossart HP, Schweitzer B, Ploug H (2002) Microbial ecology of organic aggregates in aquatic ecosystems. Aquat Microb Ecol 28: 175-211.

Sokal RR, Rohlf FJ (1995) Biometry: The Principles and Practice of Statistics in Biological Research, 3rd edition. Freeman, San Francisco, 887 pp.

Stevens H, Brinkoff T, Rink B, Vollmers J, Simon M (2007) Diversity and abundance of Gram positive bacteria in a tidal flat ecosystem. Environ Microbiol 9: 1810-1822.

Stotzky G (1997) Soil as an environment for microbial life. In: Modern Soil Microbiology (eds van Elsas JD, Trevors JT, Wellington EMH). Marcel Dekker, New York, pp. 1-20.

Tholosan O, Bianchi A (1998) Bacterial distribution and activity at the water-sediment boundary layer on NW Mediterranean continental margin. Mar Ecol Prog Ser 168: 273-283.
Torsvik V, Daae FL, Sandaa R-A, Øvreås L (1998) Novel techniques for analysing microbial diversity in natural and perturbed environments. J Biotechnol 64: 53-62.

Torsvik V, Øvreås, L (2002) Microbial diversity and function in soil: from genes to ecosystems. Curr Opin Microbiol 5: 240-245.

Torsvik V, Sørheim R, Goksøyr J (1996) Total bacterial diversity in soil and sediment communities-a review. J Ind Microbiol 17: 170-178.

Vetter YA, Deming JW, Jumars PA, Krieger-Brockett BB (1998) A predictive model of bacterial foraging by means of freely released extracellular enzymes. Microb Ecol 36: 75-92.

Yim G, Wang HMH, Davies J (2007) Antibiotics as signalling molecules. Proc R Soc Lond B, Biol Sci 362: 1195-1200. 